\title{
NOTA INTRODUCTORIA
}

\author{
Javier de Navascués \\ Universidad de Navarra \\ jnavascu@unav.es
}

Refiriéndose a su propia ficción, decía Julio Ramón Ribeyro que él cultivaba una maceta. A pesar de su modestia, la figura central de Ribeyro pesa más hoy que la de sus contemporáneos, más atentos a las dimensiones de la novela, en la configuración del patrón ideal del cuento en Perú. En efecto, a partir de la segunda mitad del siglo, parece que el foco de la narrativa breve en el Perú viene mediada por el retrato de una clase media a la que se aboca la generación del 50. Sin embargo, la dichosa conjunción de realismo urbano y escritura autobiográfica que dio la fama al autor de Sólo para fumadores, no debiera oscurecer el conocimiento de otras vetas que han sido exploradas con éxito notable. Así, una mirada a la producción en las provincias, como el que se propone en algunos de los artículos de este número, nos muestra una atención por las tradiciones populares que enriquece nuestro información sobre el cuento, al margen de los senderos trillados por el indigenismo de creadores y críticos. De la misma manera el peso del relato oral en la vida cotidiana, que ha dado lugar a diversas antologías, tiene su reflejo también en la producción de muchos otros narradores brevísimos. En esta línea no debemos olvidar el auge de la minificción, que se acompasa con el que experimenta en todo el mundo hispánico. Carlos Rengifo, Grecia Cáceres, Houdini Guerrero, Jack James Flores Vega o Fernando Iwasaki debieran figurar en cualquier selección de minificción peruana.

A lo largo del siglo XX la heterogénea realidad del país ha ofrecido un paisaje espectacular para la imaginación de cuentistas que han ido cultivando el testimonio antropológico, la evocación lírica, el vuelo fantástico, el humor transgresor o la denuncia política. Cada una de estas variantes han ido apareciendo en exclusiva o en combinación unas con otras, demostrando la profunda hibridación tan característica del campo literario peruano. Uno de los nombres de creciente prestigio en su generación, Edgardo Rivera Martínez, es un exacto representante de esa conjunción de mundos. No por azar a él se dedican dos estudios en el presente número de la revista Lejana.

No se puede escribir una historia de la literatura hispanoamericana sin tener muy en cuenta nombres como Mario Vargas Llosa, José María Arguedas, Ciro Alegría o Alfredo Bryce Echenique, cada uno de ellos valorados ante todo en su faceta de novelistas. Sin embargo, el cuento peruano tiene una riqueza que va más allá de los nombres canónicos y, poco a poco, la crítica va adentrándose en la obra de aquellos otros que completan el panorama. En el presente número, gracias al interés y la colaboración de destacados especialistas, se recorren esas vías menos transitadas que revelan la riqueza del cuento peruano desde el modernismo de Valdelomar hasta nuestros días.

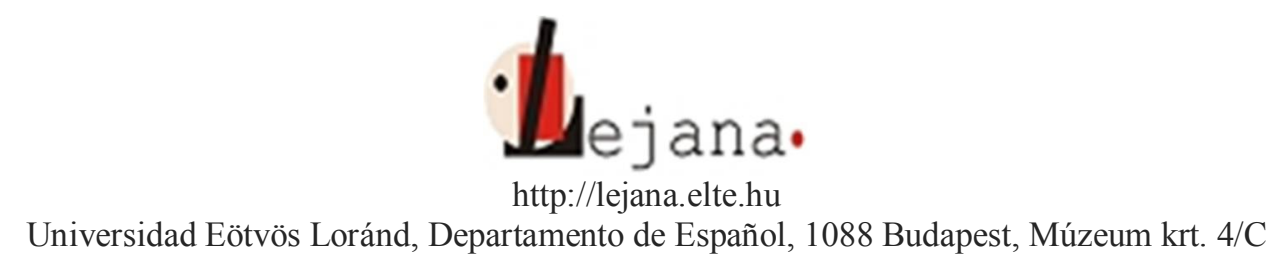

